\title{
Studies of Glucagon Effects on Insulin Secretion :
}

\section{a Clinical Aspet}

\author{
Kohei KURODA \\ The Second Department of Internal Medicine, Faculty of Medicine, Osaka University, Osaka \\ (Director : Professor Mitsuo Nishikawa)
}

Although it has been well established that glucose is the major stimulus for insulin release, glucagon has been also reported to stimulate insulin release independent of its hyperglycemic action. The present study was undertaken to investigate an interaction of these insulinogenic substances and to explore the physiological effect of glucagon on insulin secretion.

Plasma insulin responses to an intravenous administration of $1 \mathrm{mg}$ glucagon and/ or $25 \mathrm{gm}$ glucose were studied in normals, mild diabetic $(\mathrm{FBS}<120 \mathrm{mg} \%$ ) and severe diabetic (FBS $>200 \mathrm{mg} \%$ ) patients. Furthermore, the effect on insulin secretion of very small amounts of glucagon causing an increase in plasma concentration of glucagon within a physiological range was studied in the presence or absence of hyperglycemia in healthy volunteers.

After an intravenous administration of $25 \mathrm{gm}$ glucose, plasma insulin levels rose promptly in every group, reaching mean peaks of $120 \mu \mathrm{u} / \mathrm{ml}$ in normal, $43 \mu \mathrm{u} / \mathrm{ml}$ in mild diabetic and $7 \mu \mathrm{u} / \mathrm{ml}$ in severe diabetic group. Following an administration of $1 \mathrm{mg}$ glucagon, plasma insulin level rose to the same extent as that following intravenous $25 \mathrm{gm}$ glucose load in every group and the rapid increase in IRI concentration occurred prior to any change in blood glucose following the glucagon administration. Glucose combined with glucagon elicited a striking elevation of plasma insulin concentration and the insulin levels attained at corresponding times, after an injection of glucose and glucagon together, exceeded the sum of those attained when glucose or glucagon was given individually, although no difference in blood glucose change was observed between glucose together with glucagon and glucose alone. The synergistic effect of glucose and glucagon on insulin secretion was demonstrated most eminently in the mild diabetics of three groups.

An intravenous injection of $0.05 \mathrm{mg}$ of glucagon in healty volunteers caused about a fourfold rise in plasma insulin concentration five minutes after the load; about $70 \%$ increase in plasma insulin level was observed 20 minutes after the intravenous injection of $0.01 \mathrm{mg}$ of glucagon; no elevation of plasma insulin occurred following the administration of $0.005 \mathrm{mg}$ of glucagon. A slight increase in plasma glucagon level was caused by $0.005 \mathrm{mg}$ of glucagon but it was a variation within the physiological range. Under a certain degree of hyperglycemia brought about by a continuous infusion of glucose at the rate of $6 \mathrm{mg}$ per $\mathrm{kg}$ body weight per minute, however, the intravenous admini- 
stration of $0.005 \mathrm{mg}$ of glucagon prompted a sharp and significant elevation of plasma insulin concentration.

The fact that the combined administration of glucose and glucagon, even in such a small dose as $0.005 \mathrm{mg}$, which has no effect on insulin secretion per se, markedly enhanced the insulin release, suggests that glucose and glucagon act synergistically to insulin release.

(See pp. 1418 1423) 


\section{グルカゴンのインスリンの分泌に及ぼす影響}

\section{II 家鬼膵切片を用いての実験的研究}

大阪大学医学部内科学第 2 教室（主任：西川光夫教授）

黒田耕平

（昭和48年 8 月27日受付）

ブドウ糖とグルカゴンのインスリン分泌に対する相互関係を家鬼膵切片を用いた in vitro 系で検討 した．グルカゴンにより有意の IRI 放出の増大をきたすにはブドウ糖濃度 $60 \mathrm{mg} \%$ では $2.5 \mu \mathrm{g} / \mathrm{ml}$ 以 上のグルカゴンが必要であり， $80 \mathrm{mg} \%$ 以上では $1 \mu \mathrm{g} / \mathrm{ml}$ のグルカゴンで充分であつた．又 $150 \mathrm{mg} \%$ のブドウ糖存在下では $0.1 \mu \mathrm{g} / \mathrm{ml}$ のグルカゴン添加により IRI 放出量が増大した。 てれらの成績はブ ドウ糖とグルカゴンがインスリン分泌に対し相乗的に作用する事を示している.

\section{I 緒言}

近年グルカゴンは血糖上昇作用とは別個にインスリン分泌能を有する事が明らかとなつた ${ }^{122)}$.

勿論，インスリン分泌を調節する最も重要な因子はブドウ糖であるが，ブドウ糖以外の因子もインスリン 分泌に関与している事が証明されており ${ }^{334)}$ ，グルカゴンもその一因子である可能性は否定し得ない.

そてで著者はグルカゴンのもつインスリン分泌能をインスリン分泌の最も重要な調節因子であるブドウ糖 との相互関係より検討し，グルカゴンのインスリン分泌に及ぼす生理的意義の解明を試みた。

さきに著者は人にグルカゴンを投与した場合，その投与量が薬理量であつても又生理量であつてもブドウ 糖と相乗的に作用してインスリン分泌を促進せしめる事を明らかにし，グルカゴンが生理的にもインスリン 分泌に関与している可能性のある事を示唆したが，本論文ではインスリン分泌に対するブドウ糖とグルカゴ ンの相互関係を家鬼膵切片を用いた in vitro 系において検討した。

\section{II 実験材料及び実験方法}

Coore and Randle ${ }^{5)}$ の方法により家郈荟切片を用いブドウ糖及びグルカゴンによるインスリン分师を検索 した. 即ち一夜絶食せしめた家鬼（体重 2000〜2500gm）を pentobarbital-Na により屠殺，その膵を1片 が50〜80mg になるよう細分し， Table 1 に示す様なデザインに従って incubation を行なつた. 先ず $60 \mathrm{mg}$ \%の濃度のブドウ糖, 0.3\%牛血清アルブミンを含む Krebs-Henseleit bicarbonate buffer 中で45分間 preincubate する. そののち 4 ケの膵小片をプールして, 上記の medium に $1000 \mathrm{KIU} / \mathrm{ml}$ の trasylol を添加 した溶液 $3 \mathrm{ml}$ 中で15分間 incubate する (control). 次にてれらの膵小片を前記の medium に種々の濃度 のブドウ糖又はグルカゴン，あるいはこの両者を加えた別の medium 中で15分間 incubate する (test A). 同一膵組織でての操作を繰返し (test B), control, test A, test B の各 medium 中に放出されたインスリ ン量を radioimmunoassay（RGC のインスリン測定用キット使用）で測定した。尚ての実験に用いたグル カゴンは Lilly 社の結晶膵グルカゴンで，そのグルカゴン $1 \mathrm{mg}$ 中の immunoreactive insulin (IRI) 含 量は $3.0 \mathrm{mu}$ 乃至 $6.2 \mathrm{mu}$ であつた。

実駼結果は Table 1 亿示す如く最初の incubation medium 中に放出されるIRI 量 C を100\%とし，同 一膵組織がそれぞれの test medium 中に放出したIRI 量A又はBをそれぞれ対照 $(\mathrm{C})$ との百分比で表現 
Table 1. Design of experiment and expression of results obtained.

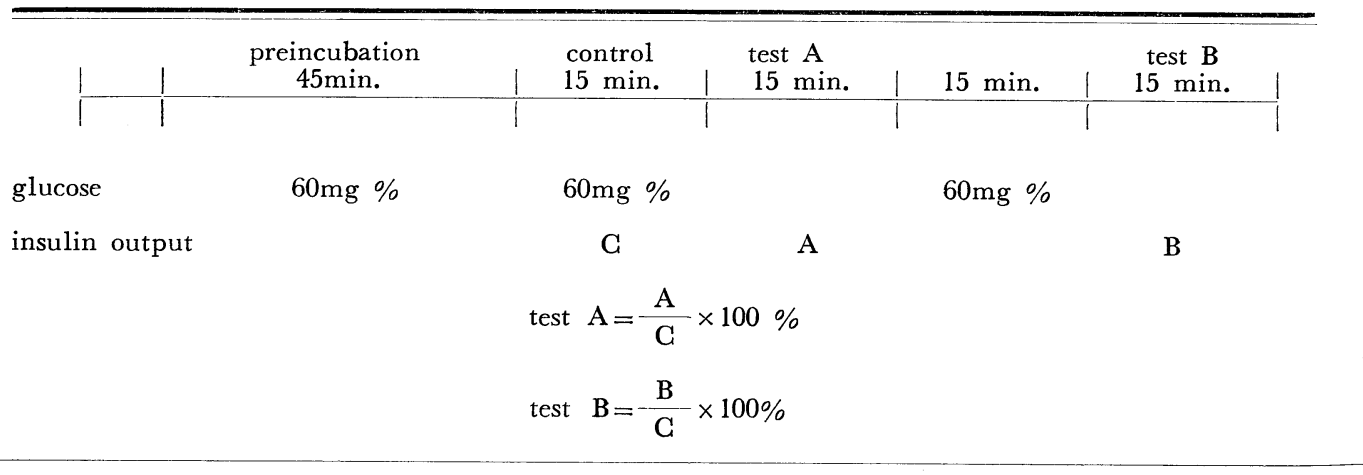

した．ブドウ糖以外にインスリン分泌刺激物質を添加しない場合，A及び $\mathrm{B}$ のンスリン分泌には明らかな 差のないととを予め確かめている。

\section{III 成績}

ブドウ糖謈度と IRI 放出量の関係は Fig. 1 の如 くで，ブドウ糖濃度 $60 \mathrm{mg} \%$ でのIRI 放出量を前 述の如く $100 \%$ とすると $80 \mathrm{mg} \%$ の漉度のブドウ糖 によるIRI 放出量は $102 \%$ と対照（C）との間に有 意差を認めなかつたが，100mg \%以上の濃度のブ ドウ糖存在下ではブドウ糖濃度が増大するとともに IRI 放出量も有意に増加した.

次いで $60 \mathrm{mg} \%$ \%゙ドウ糖存在下で種々の濃度 のグルカゴンを添加した場合の medium 中への IRI 放出量を Fig. 2 亿示した. medium 中のグ ルカゴン濃度が $1 \mu \mathrm{g} / \mathrm{ml}$ 以下の場合, その IRI 放 出量はグルカゴン無添加群との間に差を認めないが, medium 中のグルカゴン濃度が $2.5 \mu \mathrm{g} / \mathrm{ml}$ 以上の場 合にはグルカゴン浱度が増大するに伴い IRI 放出 量も増加した。

次に，ブドウ糖源度が $60 \mathrm{mg} \%$ の際に IRI 放出 効果を認めなかつた $1 \mu \mathrm{g} / \mathrm{ml}$ のグルカゴンを， 60 $\mathrm{mg} \%$ より $300 \mathrm{mg} \%$ 種々の濃度のブドウ糖を含 む medium 中に添加して比較すると，そのIRI 放 出量はブドウ糖濃度 $80 \mathrm{mg} \%$ 以上でグルカゴン無 添加群に比し明らかな增大を認めた (Fig. 3).
Fig. 1. Effect of glucose on insulin output from the rabbit pancreas.

Result is expressed as per cent of the value obtained in the control experiment in which the incubation medium containing $60 \mathrm{mg} \%$ of glucose is employed.

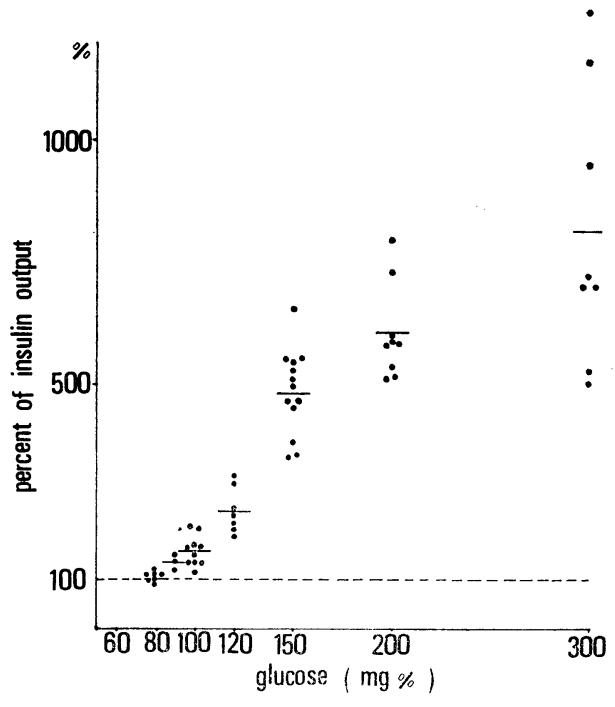

すなわち $1 \mu \mathrm{g} / \mathrm{ml}$ のグルカゴンの添加は荟切片よりの IRI 分泌を惹起せしめるに必要なブドウ糖の最少 濃度を $80 \mathrm{mg} \%$ \%迄ひきさげたのであり，てのととは Fig.4亿よつて明らかに示される.

次に medium 中のブドウ糖濃度を $150 \mathrm{mg} \%$ と高濃度にして種々の濃度のグルカゴンを添加した場合の IRI 放出効果を検討した。乙の場合グルカゴン添加によるIRI 放出効果の有無を判定し易くする為， 150 $\mathrm{mg} \%$ \%漉度のブドウ糖のみを含む medium 中に放出される IRI 量を100\%としてその結果を表現した。 
Fig. 2. Effect of glucagon on insulin output from the rabbit pancreas.

Per cent of insulin output is expressed in the same way as in Fig. 1.

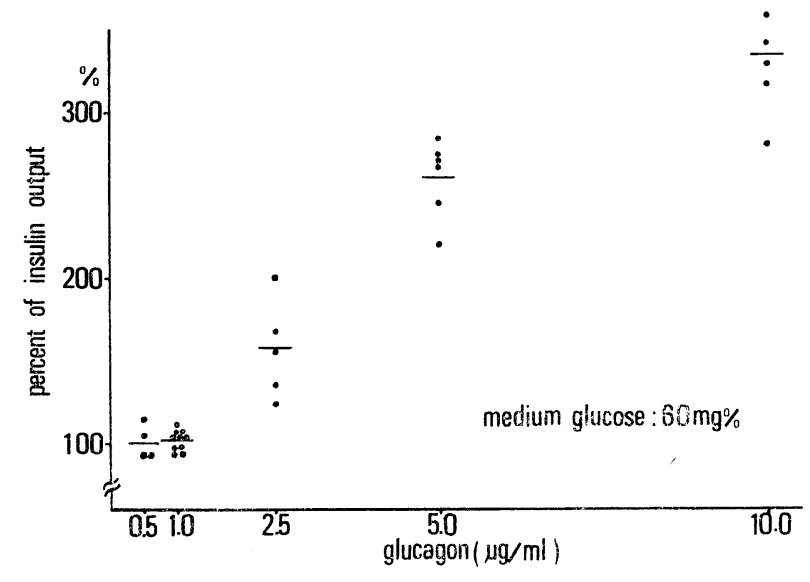

Fig. 3. Synergistic effect of glucose and glucagon on insulin output from the rabbit pancreas.

Per cent of insulin output is expressed in the same way as in Fig. 1.

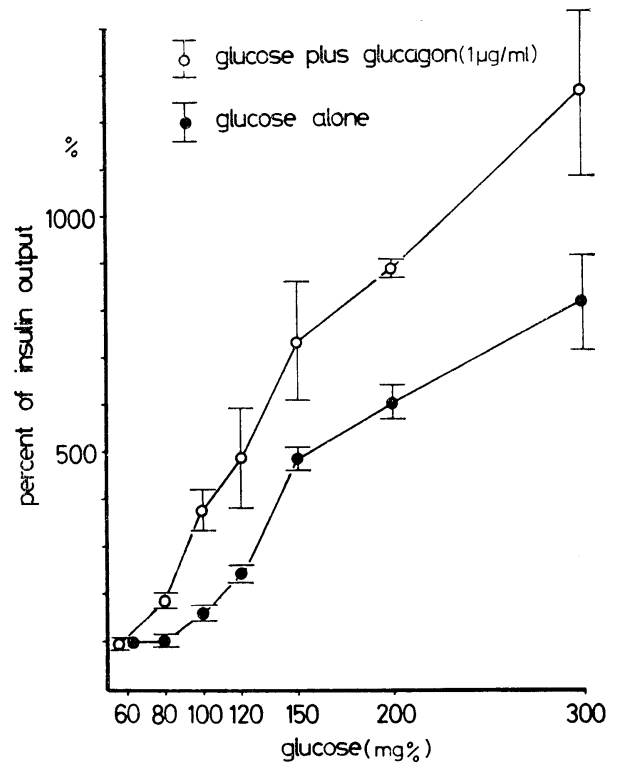

その成績は Fig. 5 亿示す如くで，ブドウ 糖濃度が $60 \mathrm{mg} \%$ の際に IRI 放出効果を認めなかった $1 \mu \mathrm{g} / \mathrm{ml}$ のグルカゴン添加で $178 \pm 22 \%$ と明らかな IRI 放出の増大を認もたのみならず, $0.1 \mu \mathrm{g} / \mathrm{m} 1$ と更に低濃度の

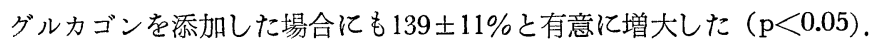


Fig. 4. Synergistic effect of glucose and glucagon on insulin output from the rabbit pancreas.

Per cent of insulin output is expressed in the same way as in Fig. 1.

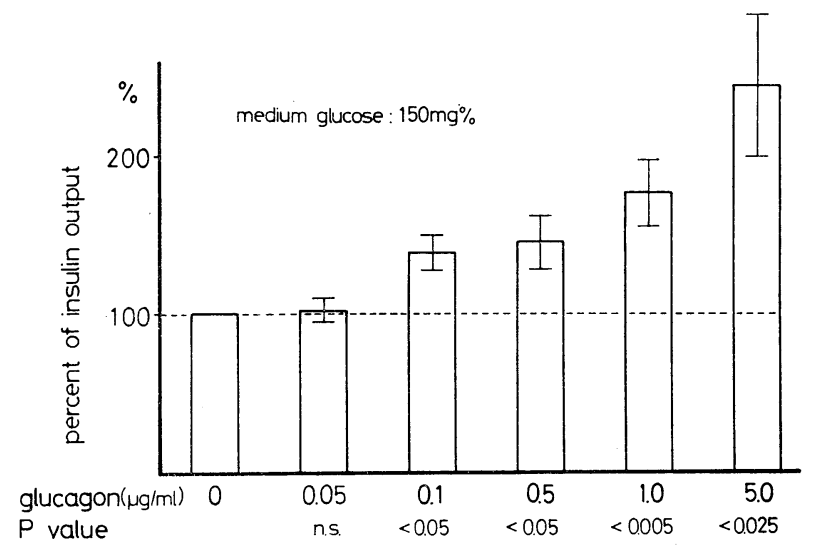

Fig. 5. Effect of glucagon on insulin output from the rabbit pancreas.

Result is expressed as per cent of the value obtained in the control experiment in which the incubation medium containing $150 \mathrm{mg} \%$ of glucose is employed.

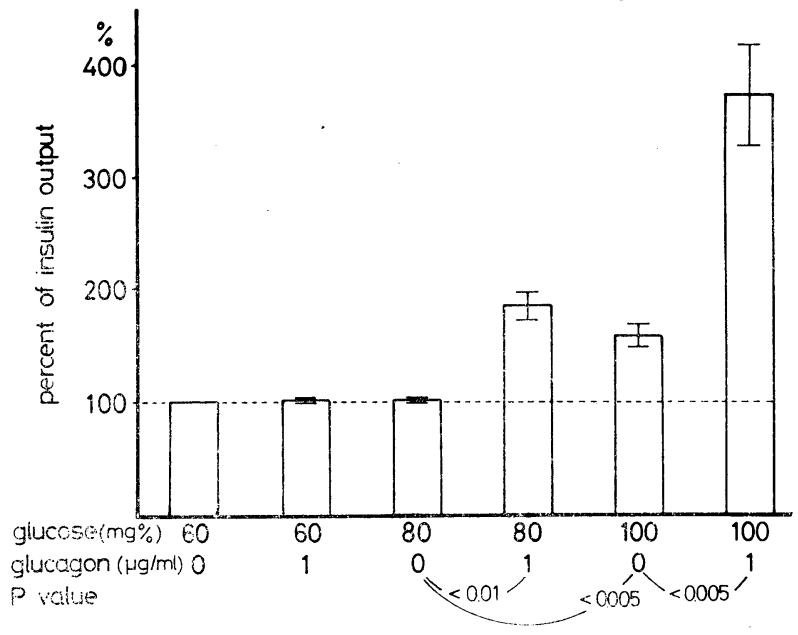

IV 考按

人に $1 \mathrm{mg}$ グルカゴンを $25 \mathrm{~g}$ ブドウ糖と同時に静脈内に負荷した際の血中 IRI 反応は, それぞれの単 独負荷時の血中 IRI 反応の和よりも大で，ブドウ糖とグルカゴンがインスリン分泌対し相乗的に作用し ているととを著者は明らかにした。ささら微量のグルカゴンを使用し血中グルカゴン濃度の増加が生理的変 動範围内にとどまつても上述の相乗作用は認められた。

以上 in vivo で認められたてれらの諸事実は, in vitro の実験でも再現し得た。即ち, medium 中のブド ウ糖莀度が $80 \mathrm{mg} \%$ \%埸合そのインスリン放出量は対照 (C, Table 1) との間に有意差を認めないが，1 $\mu \mathrm{g} /$ $\mathrm{ml}$ のグルカゴンを添加するとそのインスリン放出量は対照（C, Table 1) に比し有意に増大し, 更にての 
$1 \mu \mathrm{g} / \mathrm{ml}$ のグルカゴンを $80 \mathrm{mg} \%$ 以上の種々の濃度のブドウ糖を含む medium 中に添加した際もそのイン スリン放出量はグルカゴン整添加群に比し明らかに増大した。 又, medium 中のブドウ糖濃度が $60 \mathrm{mg} \%$ の際には， $1 \mu \mathrm{g} / \mathrm{ml}$ 以下の濃度のグルカゴン添加ではインスリン分泌増強効果を示さなかつたが， medium 中のブドウ糖濃度を $150 \mathrm{mg} \%$ と高濃度にすると $0.1 \mu \mathrm{g} / \mathrm{ml}$ と少量のグルカゴン添加によつてもブドウ糖単 独時に比し明らかなインスリン放出量の增大が認められた。

これらの成績は in vitro においてもブドウ糖とグルカゴンがインスリン分泌に関し相乗的に作用する事 を示すと共に，グルカゴンの存在下では同一量のインスリン分泌を惹起せしめる為にはブドウ糖単独時に比 しょり低濃度のブドウ糖で充分であり, 又一方比較的低濃度のグルカゴンがインスリン分泌促進効果を発揮 するためにはある濃度以上のブドウ糖の存在が必要である事を示唆している.

さて，以上記述した如くグルカゴンがインスリン分泌能を有しさらにブドウ糖と相乗作用を示す事は明ら かであるが，如何なる機序を介してその効果を発揮するかは充分な解明がなされておらず，未だ憶測の域を 出ない．しかしグルカゴンは膵ラ氏島内の cyclic AMP 濃度を上昇さす事が知られており ${ }^{6)}$ ，一方ての cyclic AMP はインスリン分泌を促進さすという成績が報告されている7). 又 cyclic AMP の分解醉素であ る phosphodiesterase の活性を抑制する theophilline がインスリン分泌刺激物質によるインスリン分泌を 増强する事が報告されており，てれらの諸事実を考え合せるとグルカゴンは cyclic AMP を介してインスリ ン分泌を促進さしているという推論が可能である。たで最近のCharles ら ${ }^{9}$ の成績では $\beta$ 細胞内 cyclic AMP 量とインスリン分泌量が必ずしも平行しておらず，cyclic AMP のインスリン分泌に対する直接的作用には 疑義が持たれる。一方ブドウ糖によるインスリン分泌機序も必ずしも明らかではない. 即ちインスリン分泌 にとつてブドウ糖が $\beta$ 細胞内で代謝される事が必要であるとする考兊 ${ }^{510)}$ と，必ずしも代謝される必要がな いとする説がある11).しかしながら；いずれにしてもブドウ糖よりの何らかの信号がインスリン分泌の引金 になつていると考えられる，グルカゴンによって增量した cyclic AMP はブドウ糖よりの信号の生成の割 合を増大せしめるか， あるいはブドウ糖よりの信号に対する感受性を高めるかなどの結果両者の相乗作用が 発現するという想定が可能であろう。

\section{$\mathrm{V}$ 結 語}

グルカゴンのインスリン分泌に対するブドウ糖との相互関係を家鬼膵切片を用いた in vitro 系において 検討し以下の如き結果を得た。

1） medium 中のブドウ糖濃度が $60 \mathrm{mg} \%$ と低濃度の場合にも $2.5 \mu \mathrm{g} / \mathrm{ml}$ 以上のグルカゴン添加により インスリン分泟の増大が認められ, グルカゴンそのものにインスリン分泌促進作用のある事が示された.

2 ） medium 中のブドウ糖濃度が $80 \mathrm{mg} \%$ の場合のインスリン放出嘼は $60 \mathrm{mg} \%$ 場合のそれと有意差 はないが，てこに 60mg \%ブドウ糖存在下ではインスリン放出量の増大を来さなかつた $1 \mu \mathrm{g} / \mathrm{ml}$ のグルカ ゴンを添加すると，インスリン放出はグルカゴン非添加の場合に比し有意に増大した。 なお $80 \mathrm{mg} \%$ 上 のブドウ糖濃度においても $1 \mu \mathrm{g} / \mathrm{ml}$ のグルカゴン添加により明らかなインスリン分泌の增大が認められた。 この結果はブドウ糖とグルカゴンがインスリン分泌に対し相乗的に作用し, グルカゴンの存在下では同一量 のインスリン分泌を惹起せしめる為にはブドウ糖単独時に比しより低濃度のブドウ糖で充分である事を示唆 している.

3 ） medium คのブドウ糖濃度を $150 \mathrm{mg} \%$ と高濃度にした場合には， $0.1 \mu \mathrm{g} / \mathrm{ml}$ と非常に低濃度のグル カゴン添加によつてもIRI 放出量が増大した。 ての成績は比較的低濃度のグルカゴンもインスリン分泌に 対しブドウ糖と相乗的に作用する事を示すと共に比較的低濃度のグルカゴンがインスリン分泌促進効果を発 揮する為にはある濃度以上のブドウ糖の存在が必要である事を示唆している。

稿を終るにあたり，御想篤なる御指導，御校閲を睗わつた恩師西川光夫教授に深甚の謝意を表します。ま た直接本研究に御教示, 御伹样を戴いた垂井清一郎助教授, 並びに直接の御指導とともに種々御協力戴いた 本学中検島健二講師に心から感謝致します. 


\section{文献}

1) Samols, E., G.Marri and V. Marks : Lancet, 2 : 415, (1965).

Porte, Jr., F.G. Wood, Jr. and R.H. Williams : Metabolism, 15 : 114, (1966).

N., G.D. Holdsworth and D.S. Turner : J. Clin. Endocr., 25 : 1317, (1965).

Stimmler, C.J. Hlad, Jr. and Y. Arai : J. Clin. Endocr., 24 : 1076, (1964).
2) Grockford, P.M., D. 3) Mc Intyre,

4) Elrick, H., L.

5) Coore, H.G and P.J. Randle : Biochem. J., 93 : 66, (1964).

6) Montague, W. and J.R. Cook : Biochem.

J., $122: 115$, (1971).

7) Sussman, K.E. and G.D. Vaughan : Diabetes, $16: 449$, (1967).

8) Turtle, J.R., G.K. Littleton and D.M. Kipnis : Nature, $213: 727$, (1967).

9) Charles, M.A., R. Fanska, F.G. Schmid, P.H. Forsham and G.M. Grodsky : Science, 179 : 569, (1973). 10) Montague, W. and K.W. Taylor : Biochem. J., $115: 257$, (1969).

11) Matschinsky, F.M., J.E. Ellerman, J. Krzanowski, J. Kotler-Brajtburg, R. Landgraf and R. Fertel : J. Biol. Ghem., 246 : 1007, (1971). 